\title{
GRAMATIKALISASI VERBA HEIN DAN SEIN
}

\author{
Agus Ridwan \\ Universitas Negeri Surabaya, agusridwan@unesa.ac.id
}

\begin{abstract}
Linguistic units in any language will develop at a certain time. Such development can occur in the field of phonology, (morpho) syntax, and semantics. However, not all of linguistic units can develop in parallel on these three areas. It also occurs at the language units of German like verbs haben 'have' and sein 'to be'. The verbs haben 'have' and sein 'to be' can have function as a full verb. In addition to a full verb, the verbs haben 'have' and sein 'to be' also serve as an auxiliary verb, a functional verb and a modality verb. The various functions of verbs especially the origin of their formation certainly created problems for language expert and observer, and also German language teachers/learners. In connection with the issue, this article tries to describe the development of verbs haben 'have' and sein 'to be'. The theory used in the analysis is the theory of grammaticalization in the field of syntagmatic/paradigmatic (morpho) syntax and semantics.
\end{abstract}

Key Words: verb, auxiliary verb, full verb, functional verb, grammaticalization

\section{PENDAHULUAN}

Satuan bahasa seperti haben dan sein bisa menduduki slot predikat atau bisa dikatakan bahwa fungsi prototipe verba adalah pembentuk komponen predikat. Sebagai predikat, verba tentunya juga memiliki karakter valensi tertentu pula, yakni membutukan berbagai komplemen tergantung dari kelas verba itu sendiri seperti:

1) Ein Buch schenken

Komplemen Akusatif verb

'mengirim buku'

2) ihrer Feundin ein Buch geben

Datif Akusatif Komplemen Akusatif verb

'memberi temannya sebuah buku' 
3) seiner gedenken

Komplemen Genitif verb

'memikirkannya'

4) über Fritz reden

Komplemen Prepositif verb

'berbicara mengenai Fritz'

5) in Hamburg wohnen

Komplemen Situatif Verb

'mengirim buku'

8) erwarten, dass man gewonnen hat

Verb Komplemen dass-Satz

'mengharap bahwa sesorang telah memperolehnya"

9) erwarten, zu gewinnen

Verb Komplemen Infinitiv

'mengharap untuk memenangkan'

(Zifonun dkk. 1997a)

Seperti verba schenken 'mengirim', geben 'memberi', gedenken 'memikirkan', reden 'berbicara mengenai', wohnen 'tinggal', erwarten 'mengharap', satuan bahasa haben dan sein juga bisa digunakan sebagai verba penuh. Sebagai verba penuh, tentunya satuan bahasa tersebut membutuhkan komplemen ataupun suplemen.

Selain itu, satuan bahasa haben dan sein juga bisa digunakan sebagai verba fungsional, verba modalitas, dan verba bantu (Barz 2009). Namun, dalam bukubuku gramatik bahasa Jerman tidak ada penjelasan mengenai proses pembentukan satuan-satuan bahasa tersebut. Demikian pula perubahan makna yang dikandungnya. Hal ini tentunya menimbulkan pertanyaan bagi pemerhati bahasa, guru bahasa Jerman atau siswa yang berpikiran kritis seperti "mengapa satuan bahasa haben dan sein di satu sisi bisa digunakan sebagai verba penuh, di sisi lain satuan bahasa tersebut memiliki kelas verba yang lain?“. 
Agus Ridwan, Gramatikalisasi Verba (hal 131-153)

\section{Gramatikalisasi}

Meillet (dalam Lehmann tanpa tahun) dalam L'évolution des formes grammaticales "Evolusi Bentuk Gramatikal" pertama kali istilah gramatikalisasi. Lehmann (tanpa tahun) berpendapat bahwa gramatikalisasi merupakan suatu proses perubahan satuan bahasa. Proses perubahan tersebut terjadai dari satuan bahasa yang bersistem autonom menjadi satuan bahasa yang tetap. Di samping itu, perubahan satuan bahasa itu juga terbentuk pada tingkatan tertentu. Sejalan dengan pendapat Lehmann, Henn-Memmesheimer (2004 dan 2006) juga berpendapat bahwa gramatikalisasi merupakan salah satu teori linguistik yang digunakan untuk mendeskripsikan perkembangan suatu bahasa atau proses terbentuknya struktur baru, yakni bagaimana variasi bahasa itu terbentuk (Lehmann 1995).

Henn-Memmesheimer (2004 dan 2006) membedakan parameter gramatikalisasi secara paradigmatis dan parameter gramatikalisasi secara sintagmatis berbasis pada penggunaan teori yang diajukan Lehmann dan Girnth. Secara paradigmatis, proses gramatikalisasi meliputi reduksi fonetis (phonetische Reduktion) pada bidang fonetik, paradigmatisasi (Paradigmatisierung) dan obligatorifisasi (Obligatorifizierung) pada bidang (morfo)sintkasis, dan reduksi semantik (semantische Reduktion) pada bidang semantik. Secara sintagmatis proses gramatikalisasi juga terdiri dari tiga bidang, yaitu bidang fonetik, (morfo)sintaksis, dan semantik. Setiap bidang tersebut juga memiliki parameter sendiri, seperti fusi (Fusion) pada bidang fonetik, koalesens (Koaleszens) dan topologisasi (Topologisierung) pada bidang (morfo)sintaksis terdapat, serta synsemantisasi (Synsemantisierung) pada bidang semantik seperti pada tabel berikut. 
Tabel 1:

Proses gramatikalisasi secara paradigmatis

\begin{tabular}{|c|c|c|c|}
\hline $\begin{array}{c}\text { Gramatikalisasi } \\
\text { Bidang }\end{array}$ & $\begin{array}{c}\text { Gramatikalisasi } \\
\text { lemah } \\
\text { (Sturktur lama) }\end{array}$ & $\begin{array}{c}> \\
\text { Proses }\end{array}$ & $\begin{array}{c}\text { Gramatikalisasi } \\
\text { kuat } \\
\text { (Sturktur baru) }\end{array}$ \\
\hline \multirow{5}{*}{ FONETIK } & $\begin{array}{c}\text { Satuan bahasa } \\
\text { memiliki ciri-ciri } \\
\text { fonetik yang } \\
\text { lengkap }\end{array}$ & $\begin{array}{c}\text { Reduksi } \\
\text { bunyi }\end{array}$ & $\begin{array}{c}\text { Ciri-ciri fonetik } \\
\text { satuan bahasa } \\
\text { mengalami } \\
\text { perubahan atau } \\
\text { pelesapan }\end{array}$ \\
\hline & $\begin{array}{c}\text { Hubungan satuan } \\
\text { bahasa dengan } \\
\text { satuan bahasa } \\
\text { lainnya tidak } \\
\text { terbatas }\end{array}$ & Paradigmatiasasi & $\begin{array}{c}\text { Hubungan satuan } \\
\text { bahasa dengan } \\
\text { satuan bahasa } \\
\text { lainnya terbatas }\end{array}$ \\
\cline { 2 - 5 } & $\begin{array}{c}\text { Satuan bahasa } \\
\text { dapat } \\
\text { disubstitusikan } \\
\text { dengan satuan } \\
\text { bahasa lainnya } \\
\text { atau dilesapkan }\end{array}$ & Obligatorifisasi & $\begin{array}{c}\text { Keterbatasan } \\
\text { kookurensi }\end{array}$ \\
\hline SEMANTIK & $\begin{array}{c}\text { Satuan bahasa } \\
\text { memiliki } \\
\text { seperangkat ciri- } \\
\text { ciri semantik }\end{array}$ & Reduksi & $\begin{array}{c}\text { Satuan bahasa } \\
\text { mengalami } \\
\text { reduksi ciri-ciri } \\
\text { semantiknya }\end{array}$ \\
\hline
\end{tabular}


Tabel 2:

Proses gramatikalisasi secara sintagmatis

\begin{tabular}{|c|c|c|c|}
\hline $\begin{array}{l}\text { Gramatikalisasi } \\
\text { Bidang }\end{array}$ & $\begin{array}{c}\text { Gramatikalisasi } \\
\text { lemah } \\
\text { (Sturktur lama) }\end{array}$ & $\begin{array}{c}> \\
\text { Proses }\end{array}$ & $\begin{array}{c}\text { Gramatikalisasi } \\
\text { kuat } \\
\text { (Sturktur baru) }\end{array}$ \\
\hline FONETIK & $\begin{array}{c}\text { Satuan bahasa } \\
\text { memiliki bunyi } \\
\text { yang lengkap baik } \\
\text { bunyi segmental } \\
\text { maupun bunyi } \\
\text { suprasegmental }\end{array}$ & Fusi & $\begin{array}{l}\text { Satuan bahasa } \\
\text { mengalami } \\
\text { peleburan atau } \\
\text { perubahan bunyi } \\
\text { baik bunyi } \\
\text { segmental } \\
\text { maupun bunyi } \\
\text { suprasegmental }\end{array}$ \\
\hline \multirow[t]{2}{*}{ (MORFO)SINTAKSIS } & $\begin{array}{c}\text { Satuan bahasa } \\
\text { secara formal } \\
\text { tidak tergantung } \\
\text { pada satuan } \\
\text { bahasa lainnya } \\
\end{array}$ & Koaleszenz & $\begin{array}{l}\text { Satuan bahasa } \\
\text { secara formal } \\
\text { tergantung pada } \\
\text { satuan bahasa } \\
\text { lainnya } \\
\end{array}$ \\
\hline & $\begin{array}{c}\text { Satuan bahasa } \\
\text { memiliki } \\
\text { kebebasan pola } \\
\text { urutan kata }\end{array}$ & Topologisasi & $\begin{array}{c}\text { Satuan bahasa } \\
\text { memiliki pola } \\
\text { urutan kata } \\
\text { tertentu }\end{array}$ \\
\hline SEMANTIK & Autosemantika & Synsemantisasi & Synsemantika \\
\hline
\end{tabular}

Berkaitan dengan perubahan yang dimiliki verba haben, sein dan werden. Artikel ini menitikberatkan pada kajian bidang (morfo)sintaksis dan semantik baik secara paradigmatis maupun sintagmatis.

\section{PEMBAHASAN}

Objek kajian yang digunakan dalam artikel ini adalah verba haben 'mempunyai' dan sein '(ber)ada; adalah'. Berkaitan dengan perubahan atau perkembangan satuan bahasa tersebut, kajian ini berfokus pada bidang (morfo)sintaksis dan semantik baik secara paradigmatis maupun secara sintagmatis. 


\section{A. Gramatikalisasi secara Paradigmatis}

\section{Proses Paradigmatisasi}

Pada bidang (morfo)sintaksis satuan bahasa bisa memiliki keterkaitan yang tidak terbatas dengan satuan bahasa lainnya atau secara formal satuan bahasa tersebut tidak memiliki ketergantungan pada satuan bahasa lainnya. Satuan bahasa dengan kriteria ini merupakan satuan bahasa yang bergramatikalisasi lemah (berstruktur lama).

Seperti yang telah dijelaskan pada bab pendahuluan, salah satu kelas kata dari verba haben 'mempunyai' dan sein '(ber)ada' adalah verba penuh (transitif) haben 'mempunyai' pada contoh (1), verba penuh (intransitif) sein '(ber)ada' pada contoh (2).

1) Ich habe einen Onkel.

Pron Vv Det. Nom.

'Saya memiliki (seorang) paman'

(Barz 2009)

2) Die Kinder sind im Garten.

Det. Nom. Vv Prep.+Det Nom

'Anak-anak berada di taman itu'

(Barz 2009)

Secara paradigmatis verba penuh haben 'mempunyai' dan sein '(ber)ada' mempunyai hubungan yang tak terbatas dengan satuan bahasa (verba penuh) lainnya, yakni verba penuh haben 'mempunyai' pada contoh (1) memiliki hubungan yang relatif bebas dengan verba penuh treffen 'menemui' pada contoh (3), erwarten 'menunggu' pada contoh (4) atau verba penuh lainnya pada contoh (5) yang tak terbatas atau verb penuh haben 'mempunyai' tidak memiliki ketergantungan pada satuan bahasa lainnya seperti unsur kalimat einen Onkel 'paman'.

3) Ich treffe einen Onkel.

'Saya bertemu dengan paman'

4) Ich erwarte einen Onkel.

'Saya sedang menunggu paman' 
5) Ich ... einen reichen Onkel.

'Saya ... (seorang) paman'

Seperti verba haben, verba sein '(ber)ada' sebagai verba penuh juga merupakan verba yang berstruktur lama (bergramatikalisasi lemah) karena jenis verba tersebut memiliki hubungan yang bebas dengan verba penuh lainnya seperti verba penuh essen 'makan' pada contoh (6), verba penuh spielen 'bermain' (7) ataupun verba penuh lainnya yang tak terbatas pada contoh (8) atau verba penuh sein '(ber)ada' tidak mempunyai ketergatungan dengan unsur bahasa im Garten 'di taman'.

6) Die Kinder essen im Garten.

'Anak-anak sedang makan di taman'

7) Die Kinder spielen im Garten.

'Anak-anak sedang bermain di taman'

8) Die Kinder ... im Garten.

'Anak-anak (sedang) ... di taman'

Selanjutnya melalui proses paradigmatisasi satuan bahasa yang berstruktur lama atau memiliki gramatikalisasi lemah berkembang menjadi satuan bahasa yang berstruktur baru atau memiliki gramatikalisasi kuat. Sebagai satuan bahasa yang mempunyai struktur baru, verba fungsional (Funktionsverb) haben 'mengontrol' (9), verba bantu (Hilfsverb) haben 'telah/sudah' (10) dan verba modalitas (Modalitättsverb) haben 'harus' (11.a.) memiliki hubungan yang terbatas dengan satuan linguistik (verba) lainnya, yakni verba fungsional haben 'mengontrol' dan verba bantu haben 'telah/sudah' pada konteks tersebut tidak mempunyai padanan yang tepat dengan satuan bahasa lainnya. Bisa dikatakan juga bahwa verba fungsional haben 'mengontrol' (9) memiliki ketergantungan dengan unsus bahasa unter Kontrolle 'di bawah pengawasan' dan keberadaan verba bantu haben 'telah/sudah' pada contoh (10) tergantung pada verba partizip gelesen 'membaca'. Adapun hubungan verba modalitas haben 'harus' (11.a) dengan kelas verba lainnya tidak seketat hubungan verba fungsional haben 'mengontrol' dan verba bantu haben 'telah/sudah' dengan satuan bahasa lainnya, 
yaitu ketergantungan verba modalitas haben 'harus' (11.a) pada konstruksi infinitiv (Infinitivkonstruktion) tidak seketat ketergantungan verba fungsional atau verba bantu verba bantu. Oleh karena itu verba verba modalitas haben 'harus' (11.a) masih memungkinkan mempunyai hubungan dengan verba yang berkonstruksi zu Infinitiv lainnya seperti versuchen 'mencoba' (11.b).

9) Wir haben alles unter Kontrolle.

Pron. VF Pron. Prep. Nom.

'Kami mengontrol semuanya'

(Barz 2009)

10) Ich habe gelesen.

Pron. VB VPart.

'Saya sudah membaca'

(Wahrig 2007)

11) a. Ich habe noch zu arbeiten.

Pron. VB Adv. Prep. Vv

'Saya masih harus bekerja'

(Wahrig 2007)

b. Ich versuche noch zu arbeiten.

'Saya masih bisa bekerja'

Seperti verba haben, melalui proses paradigmatisasi, verba sein juga bisa menjadi verba yang berstruktur baru atau memiliki gramatikalisasi kuat karena hubungan verba sein dengan verba lainnya terbatas atau relatif ketat. Dalam hal itu, verba fungsional sein memiliki ketergatungan dengan unsur bahasa in Bewegung dan dua satuan bahasa tersebut membentuk kolokasi atau jenis fraseologi yang berkaitan dengan penambahan verbal fungsional (verbale Funktionsverbgefüge) in Bewegung sein 'bergerak' (12).

12) Seine Finger sind ständig in Bewegung.

Pron. Nom. VF Adv. Prep. Nom

'Jari-jarinya selalu bergerak'

(Barz 2009) 
Agus Ridwan, Gramatikalisasi Verba (hal 131-153)

Demikian pula verba bantu sein 'telah/sudah' juga mempunyai keterbatasan hubungan dengan verba lainnya. Dalam hal ini, keberadaan verba bantu sein 'telah/sudah' tergantung pada verba partizip kommen 'datang'. Oleh karena itu verba bantu sein 'telah/sudah' seperti pada contoh (13) merupakah satuan bahasa yang berstruktur baru atau memiliki gramatikalisasi kuat.

13) Ich bin gekommen.

Pron. VB VPart.

'Saya sudah datang'

(Wahrig 2007)

Selain verba fungsional dan verba bantu, verba sein juga bisa digunakan sebagai verba kopula. Sebagai verba kopula, verba sein 'adalah' berada di antara verba kopula werden dan verba kopula bleiben. Berkaitan dengan karakter gramatikalisasi yang dimilikinya, verba kopula 'adalah' (14) memiliki struktur baru atau gramatikalisasi kuat sebab verba tersebut hanya memiliki hubungan yang terbatas dengan verba lainnya, yaitu verba kopula werden (15) dan verba kopula bleiben (16).

14) Jürgen war mein bester Freund.

Nom. VK Pron. Adj. Nom.

'Dulu Jürgen (adalah) teman baikku'

(Barz 2009)

15) Jürgen wurde mein bester Freund.

Nom. VK Pron. Adj. Nom.

'Dulu Jürgen (adalah) teman baikku'

(Barz 2009)

16) Jürgen bleibt mein bester Freund.

Nom. VK Pron. Adj. Nom.

'Dulu Jürgen (adalah) teman baikku'

(Barz 2009) 


\section{Proses Obligatorifisasi}

Pada bidang (morfo)sintaksis terdapat pula satuan bahasa yang mempunyai struktur lama atau gramatikalisasi lemah, jika satuan bahasa tersebut bisa disubstitusikan dengan satuan bahasa lainnya atau bisa dilesapkan sesuai dengan konteks. Verba penuh haben 'memepunyai' pada tuturan (17) secara paradigmatis dapat disubstitusikan dengan verba penuh lainnya, yakni verba penuh seperti trefen 'menemui', erwarten 'menunggu' dapat mengisi slot verba penuh haben 'memepunyai' pada tuturan (18).

17) Ich habe einen Onkel.

Pron Vv Det. Nom.

'Saya memiliki (seorang) paman'

(Barz 2009)

\section{8) Ich treffe 'menemui' einen Onkel. erwarte 'menunggu'}

Adapun verba penuh sein '(ber)ada' seperti pada contoh (19) yang bisa disubstitusikan dengan verba penuh essen 'makan' dan verba penuh spielen 'bermain' pada contoh (20) juga merupakan satuan bahasa yang memiliki struktur lama atau gramatikalisasi lemah.

Die Kinder sind im Garten.

Det. Nom. Vv Prep.+Det Nom

'Anak-anak berada di taman itu'

(Barz 2009)

Die Kinder essen 'makan' im Garten.

\section{spielen 'bermain'}

Selanjutnya baik verba fungsional haben (21) maupun verba fungsional sein (22) merupakan satuan bahasa yang berstruktur baru atau mempuyai gramatikalisasi kuat. Dalam hal ini, dua verba fungsional tersebut tidak memiliki hubungan dengan kelas verba lainnya atau tidak bisa disubstitusikan dengan kelas verba lainnya.

140 | E-ISSN: 2527-8754 http:// journal.unesa.ac.id/index.php/Paramasastra 
Agus Ridwan, Gramatikalisasi Verba (hal 131-153)

21)Wir haben alles unter Kontrolle.

Pron. VF Pron. Prep. Nom.

'Kami mengontrol semuanya'

(Barz 2009)

22) Seine Finger sind ständig in Bewegung.

Pron. Nom. VF Adv. Prep. Nom

'Jari-jarinya selalu bergerak'

(Barz 2009)

Seperti verba fungsional, verba haben 'telah/sudah' (23) dan verba sein 'telah/sudah' (24) juga bergramatikalisasi kuat, karena verba haben 'telah/sudah' hanya memiliki hubungan yang terbatas dengan verba sein 'telah/sudah' dan dua verba tersebut juga tidak bisa saling mengisi slot predikat seperti pada contoh (25), (26).

23) Ich habe gelesen.

Pron. VB VPart.

'Saya sudah membaca'

(Wahrig 2007)

24) Ich bin gekommen.

Pron. VB VPart.

'Saya sudah datang'

(Wahrig 2007)

25) Ich *bin gelesen.

Pron. VB VPart.

'Saya sudah membaca'

(Wahrig 2007)

26) Ich *habe gekommen.

Pron. VB VPart.

'Saya sudah datang'

(Wahrig 2007) 
Dibandingkan dengan verba fungsional dan verba bantu, verba kopula haben 'telah/sudah' (27) dan verba sein 'telah/sudah' (28) memiliki hubungan yang relatif terbuka. Dalam hal ini, baik verba kopula haben 'telah/sudah' maupun verba sein 'telah/sudah' bisa saling mengisi slot predikat masing-masing. Namun, dalam koridor ini, dua verba kopula tersebut masih tetap sebagai satuan bahasa yang berstruktur baru atau memiliki gramatikalisasi kuat.

27) Jürgen war mein bester Freund.

Nom. VK Pron. Adj. Nom.

'Dulu Jürgen (adalah) teman baikku'

(Barz 2009)

28) Jürgen wurde mein bester Freund.

Nom. VK Pron. Adj. Nom.

'Dulu Jürgen (adalah) teman baikku'

(Barz 2009)

\section{Proses Reduksi Makna}

Pada bidang semantik satuan bahasa bisa memiliki ciri-ciri semantik lengkap bisa juga mengalami reduksi maknanya. Satuan bahasa yang memiliki ciri-ciri semantik lengkat tersebut merupakan satuan bahasa yang berstruktur lama atau memiliki gramatikalisasi lemah. Berkaitan dengan karakter gramatikalisasi tersebut khususnya yang berkaitan dengan makna, verba penuh haben memiliki seperangkat ciri semantik seperti makna 'mempunyai'(29), 'mengenakan' (30), 'belajar' (31), 'mendapat' (32), 'terdapat; ada' (dan verba penuh sein 'berada' merupakan verba yang berstruktur lama.

29) Ich habe ein Haus

Pron Vv Det. Nom.

'Saya memiliki (sebuah) rumah'

(Drosdowski dkk. 1997)

30)Man hat jetzt wieder längere Röcke.

Pron Vv Adv. Adv. Adj. Nom.

'Saat ini orang-orang mengenakan rock yang lebih panjang lagi'

(Drosdowski dkk. 1997) 
Agus Ridwan, Gramatikalisasi Verba (hal 131-153)

31) Wir haben im Gymnasium Latein und Griechisch.

Pron Vv Prep+Det Nom. Nom. Prep. Nom.

'Kami mempelajari bahasa Latin dan bahasa Yunani di SMU'

(Drosdowski dkk. 1997)

32)Kann ich mal das Handbuch wieder haben?

VM Pron. Adv. Det. Nom. Adv. VV

'Bolehkah saya memperoleh lagi buku pegangan itu'

(Drosdowski dkk. 1997)

33) Hier hat es viele Häuser.

Adv. VV Pron Adv. Nom.

'Di sini terdapat banyak rumah'

(Drosdowski dkk. 1997)

Demikian pula verba penuh sein yang mempunyai seperangkat ciri-ciri semantik seperti '(ber)ada; terdapat' (34), 'berlangsung' (35), 'terjadi' (36):

34) In diesem Bach sind viele Fische.

Prep. Pron. Nom. VV Adj. Nom.

'Di selokan ini terdapat banyak ikan'

(Drosdowski dkk. 1997)

35)Die Vorlesung ist morgen.

Det. Nom. VV Adv.

'Kuliah ini berlangsung besuk'

(Drosdowski dkk. 1997)

36) Das letzte Erbeben wardort um 1900.

Det.Adj. Nom. VV Adv. Prep. Num.

'Gempa bumi yang terakhir itu terjadi sekitar tahun 1900 di sana'

(Drosdowski dkk. 1997)

Di samping itu satuan bahasa dengan gramatikalisasi lemah (struktur lama) bisa mengalami perubahan atau perkembangan maknanya. Melalui proses reduksi makna, satuan bahasa dengan gramatikalisasi lemah (struktur lama) menjadi satuan gramatikalisasi kuat (struktur baru). Bisa juga dikatakan bahwa satuan 
bahasa yang ciri-ciri semantiknya seperti verba penuh haben pada contoh (29)(33) dan verba penuh sein (34)-(36) bisa mengalami reduksi makna menjadi satuan bahasa atau verba fungsional, verba modalitas, dan verba bantu, misalnya verba fungsional haben akan bermakna tetap jika diikuti oleh unsur bahasa unter Kontrolle 'di bawah pengawasan' (37).

37) Wir haben alles unter Kontrolle.

Pron. VF Pron. Prep. Nom.

'Kami mengontrol semuanya'

(Barz 2009)

Demikian pula makna verba fungsional sein juga memiliki makna tetap, jika diikuti oleh unsur bahasa in Bewegung 'dalam pergerakan' (38).

38) Seine Finger sind ständig in Bewegung.

Pron. Nom. VF Adv. Prep. Nom

'Jari-jarinya selalu bergerak'

(Barz 2009)

\section{B. Gramatikalisasi secara Sintagmatis}

\section{Proses Koalesens}

Secara sintagmatis, satuan bahasa bisa mempunyai struktur lama (gramatikalisasi lemah) pada bidang (morfo)sintaksis, jika satuan bahasa tersebut tidak tergantung pada satuan bahasa lainnya, misalnya verba penuh haben 'mempunyai' (35) dan verba penuh sein 'berada'

39) Ich habe einen Onkel.

Pron Vv Det. Nom.

'Saya memiliki (seorang) paman'

(Barz 2009)

Die Kinder sind im Garten.

Det. Nom. Vv Prep.+Det Nom

'Anak-anak berada di taman itu'

(Barz 2009)

Selanjutnya melalui proses koalesens satuan bahasa struktur baru dengan struktur lama (gramatikalisasi lemah) bisa menjadi satuan bahasa dengan 144 | E-ISSN: 2527-8754 http:// journal.unesa.ac.id/index.php/Paramasastra 
(gramatikalisasi kuat). Dalam hal ini perubahan atau perkembangan struktur tersebut bisa melalui beberapa tahapan misalnya tahap pertama pada posisi Juxta, kedua : klitisisasi, ketiga : aglutinasi, dan terakhir peleburan, misalnya verba penuh haben 'mempunyai' mengalami klitisasi dengan determinitum (kata sandang) einen 'seorang'.

\section{1) Ich hab'n Buch.}

Pron Vv+Det. Nom.

'Saya memiliki (sebuah) buku'

Pembentukan klitisasi juga bisa terjadi pada verba bantu haben 'telah/sudah' pada contoh (38).

\section{2) Ich hab'n Buch gelesen.}

Pron VV+Det. Nom. VPart.

'Saya sudah membaca sebuah buku'

Namun, dalam hal ini, secara sintagmatis verba bantu haben 'telah/sudah' pada contoh (42) tetap sebagai satuan bahasa yang memiliki struktur baru atau gramatikalisasi kuat, karena sebagai verba bantu haben 'telah/sudah', satuan bahasa tersebut secara sintagmatis juga tidak memiliki pola urutan yang bebas seperti verba penuh haben 'mempunyai'.

\section{Proses Topologisasi}

Secara sintagmatis satuan bahasa juga bisa memiliki pola urutan yang bebas pada bidang (morfo)sintaksis. Satuan bahasa dengan pola urutan yang bebas perlu dibedakan dengan bagian kalimat yang memiliki pola urutan yang bebas dan pola urutan yang terbatas. Satuan bahasa yang mempunyai pola urutan yang bebas tersebut mempunyai gramatikalisasi yang lemah (struktur lama). Sebagai verb finit, baik verba penuh/verb fungsional/verba modalitas/verba bantu haben maupun verba penuh/verb fungsional/verba modalitas/verba bantu sein memiliki kedudukan yang tetap, yakni pada linke Klammer (LK) atau di depan Vorfeld (VF) atau sebelum Mittelfeld (MF). Adapu verba infinit gelesen 'membaca' menempati posisi Nachfeld (NF). 


\begin{tabular}{|c|c|c|c|c|c|}
\hline & Vorfeld & $\begin{array}{c}\text { Linke } \\
\text { Klammer }\end{array}$ & $\begin{array}{c}\text { Mittelfel } \\
d\end{array}$ & $\begin{array}{c}\text { Rechte } \\
\text { Klammer }\end{array}$ & $\begin{array}{c}\text { Nachfel } \\
\text { d }\end{array}$ \\
\hline $\begin{array}{l}43 \\
)\end{array}$ & Ich & habe & $\begin{array}{l}\text { einen } \\
\text { Onkel. }\end{array}$ & & \\
\hline $\begin{array}{l}44 \\
) \\
\end{array}$ & $\begin{array}{l}\text { Die } \\
\text { Kinder }\end{array}$ & sind & $\begin{array}{l}\text { im } \\
\text { Garten. }\end{array}$ & & \\
\hline $\begin{array}{l}45 \\
)\end{array}$ & Wir & haben & $\begin{array}{l}\text { alles } \\
\text { unter } \\
\text { Kontroll } \\
e .\end{array}$ & & \\
\hline $\begin{array}{l}46 \\
)\end{array}$ & $\begin{array}{l}\text { Seine } \\
\text { Finger }\end{array}$ & sind & $\begin{array}{l}\text { ständig } \\
\text { in } \\
\text { Bewegun } \\
\text { g }\end{array}$ & & \\
\hline $\begin{array}{l}47 \\
) \\
\end{array}$ & Ich & habe & noch & & $\begin{array}{l}z u \\
\text { arbeiten. }\end{array}$ \\
\hline $\begin{array}{l}48 \\
)\end{array}$ & Das & Ist & kaum & & $\begin{array}{l}z u \\
\text { verstehe } \\
n .\end{array}$ \\
\hline $\begin{array}{l}49 \\
)\end{array}$ & Ich & habe & & gelesen. & \\
\hline $\begin{array}{l}50 \\
) \\
\end{array}$ & Ich & Bin & & gekommen & \\
\hline
\end{tabular}

Namun, jika berbagai jenis verba tersebut masih menjadi bagian dari verba finit, maka perbedaan pola urutan yang dimilikinya tidak terlalu signifikan. Selanjutnya akan ada perbedaan antara verba yang memiliki pola urutan yang relatif bebas (berstruktur lama) dan verba yang berpola urutan tetap, jika verba penuh menjadi bagian dari verba infinit, misalnya verba bantu haben 'mempunyai' yang berubah menjadi verba infinit seperti gehabt 'mempunyai' tidak hanya bisa menempati posisi rechte Klammer (51), melainkan juga pada posisi Vorfeld (52) dan pada posisi Mittelfeld (53). Demikian pula verba penuh sein 'berada' sebagai verba infinit juga bisa menempati posisi rechte Klammer (54), posisi Vorfeld (55) dan posisi Mittelfeld (56). 


\begin{tabular}{|c|c|c|c|c|c|}
\hline & Vorfeld & $\begin{array}{c}\text { Linke } \\
\text { Klammer }\end{array}$ & Mittelfeld & $\begin{array}{c}\text { Rechte } \\
\text { Klammer }\end{array}$ & Nachfeld \\
\hline 51) & Ich & habe & einen Onkel & gehabt. & \\
\hline 52) & Gehabt & habe & $\begin{array}{l}\text { ich einen } \\
\text { Onkel. }\end{array}$ & & \\
\hline 53) & Ich & habe & $\begin{array}{l}\text { gehabt } \\
\text { einen } \\
\text { Onkel. }\end{array}$ & & \\
\hline 54) & $\begin{array}{l}\text { Die } \\
\text { Kinder }\end{array}$ & sind & im Garten & $\begin{array}{l}\text { gewesen } \\
\text {. }\end{array}$ & \\
\hline 55) & & sind & $\begin{array}{l}\text { die Kinder } \\
\text { im Garten. }\end{array}$ & & \\
\hline 56) & $\begin{array}{l}\text { Die } \\
\text { Kinder }\end{array}$ & sind & $\begin{array}{l}\text { gewesen im } \\
\text { Garten. }\end{array}$ & & \\
\hline
\end{tabular}

\section{Proses Synsemantisasi}

Pada bidang semantik satuan bahasa dapat mempunyai gramatikalisasi lemah (struktur lama), jika satuan bahasa tersebut merupakan autosemantika. Autosemantika di sini berkaitan dengan makna leksikal, yaitu makna yang dikandungnya itu tidak terikat oleh makna dari unsur kalimat lainnya seperti verba penuh haben 'mempunyai'

\section{7) Ich habe ein Haus.}

Pron Vv Det. Nom.

'Saya memiliki (sebuah) rumah'

(Drosdowski dkk. 1997)

58) Die Vorlesung ist morgen.

Det. Nom. VV Adv.

'Kuliah ini berlangsung besuk'

(Drosdowski dkk. 1997)

Pada bidang semantik satuan bahasa bisa mempunyai gramatikalisasi lemah (struktur lama), jika autosemantika dari satuan bahasa tersebut mengalami reduksi atau bisa dikatakan juga bahwa satuan bahasa dengan makna leksikal akan berubah menjadi satuan bahasa yang memiliki makna gramatikal seperti verba bantu haben 'telah/sudah' (59) dan verba bantu sein 'telah/sudah' (60).

59) Ich habe gelesen. 
Pron. VB VPart.

'Saya sudah membaca'

(Wahrig 2007)

60) Ich bin gekommen.

Pron. VB VPart.

'Saya sudah datang'

(Wahrig 2007)

Di samping perubahan dari satuan bahasa yang memiliki makna leksikal menjadi satuan bahasa yang bermakna gramatikal, melalui proses yang sama, satuan bahasa dengan makna leksikalnya bisa berkembang menjadi satuan bahasa yang memiliki makna sesuai dengan lingkungan pemakaiannya. Jadi dalam hal ini perubahan disini tidak menggunakan istilah abstrak seperti yang diajukan oleh Lehmann (tanpa tahun; 1995). Oleh karena itu, verba fungsional haben akan bermakna tetap jika diikuti oleh unsur bahasa unter Kontrolle 'di bawah pengawasan' (61). Demikian pula makna verba fungsional sein juga memiliki makna tetap yang diikuti oleh unsur bahasa in Bewegung 'dalam pergerakan' (62).

61) Wir haben alles unter Kontrolle.

Pron. VF Pron. Prep. Nom.

'Kami mengontrol semuanya'

(Barz 2009)

62) Seine Finger sind ständig in Bewegung.

Pron. Nom. VF Adv. Prep. Nom

'Jari-jarinya selalu bergerak'

(Barz 2009)

\section{SIMPULAN}

Berbasis pada penggunaan teori gramatikalisasi khususnya penerapan parameternya baik pada bidang (morfo)sintaksis secara paradigmatis dan sintagmatis maupun pada bidang semantik secara paradigmatis dan sintagmatis, satuan bahasa haben dan sein yang digunakan sebagai verba penuh merupakan satuan bahasa yang memiliki struktur lama atau mempunyai gramatikalisasi 
Agus Ridwan, Gramatikalisasi Verba (hal 131-153)

lemah. Sedangkan satuan bahasa yang mempunyai fungsi sebagai verba fungsional, verba modalitas, dan verba bantu merupakan satuan bahasa yang berstruktur baru atau satuan bahasa yang terbentuk dari satuan bahasa berupa verba penuh.

\section{DAFTAR RUJUKAN}

Barz, Irmhild. 2009. Die Wortbildung. Unentbehrlich für richtiges Deutsch. In: Die Grammatik. Unentbehrlich für richtiges Deutsch. 9. Auflage. Mannheim - Wien - Zürich: Dudenverlag.

Brinkmann, Hennig. 1971. Die deutsche Sprache: Gestalt und Leistung. 2., neubearbei-tete und erweiterte Auflage. Düsseldorf: Pädagögischer Verlag Schwann.

Drosdowski, Günther, dkk. 1997. Deutsches Universal Wörterbuch A-Z. Mannheim: Dudenverlag.

Engel, Ulrich. 2009. Deutsche Grammatik. 2., durchgesehene Auflage. München: IUDICIUM Verlag.

Henn-Memmesheimer, Beate. 2006. Grammatikalisierungen in verschiedenen Diskurstraditionen. In: Grammatische Untersuchungen. Analysen und Reflexionen. Gisela Zifonun zum 60 Geburtstag (= Studien zur deutschen Sprache Bd. 36). Breindl, Eva/Gunkel, Lutz/Strecker, Bruno, Hrsg. Tübingen: Narr.

Hentschel, Elke/Weydt, Harald. 2003. Handbuch der deutschen Sprache. 3., völlig neu bearbeitete Auflage. Berlin/New York: Walter de Gruyter.

Hentschel, Elke/Vogel, Peter M. 2009. Deutsche Morphologie. Berlin/New York: Walter de Gruyter.

Lehman, Christian. (tanpa tahun). Sprachtheorie. Universität Erfurt: Philosophische

Fakultät.(http://www.christianlehmann.eu/ling/ling_theo/index.html?http:// www. christianlehmann.eu/ling/ling_theo/grammatikalisierung.php diakses tanggal 10 Januari 2015). 
Lehmann, Cristhian. 1995. Synsemantika. In: Syntax Teilband 2 (=Handbücher zur Sprach- und Kommunikationswissenschaft Bd. 9.2) Ungeheuer, Gerold/ Steger, Hugo/Wiegand, Herbert Ernst, Hrsg. Berlin/New York: Walter de Gruyter.

Krifka, Manfred. 2007. Grundkurs: Semantik. Institut für deutsche Sprache und Lin-guistik HU Berlin. (http://amor.cms.huberlin.de/ h2816i3x/Lehre/2007_

GK_Semantik/GK_Semantik_2007_HO.pdf> diakses tanggal 9 September 2011).

Mentrup, Wolfgang. 1973. Verben mit einem Verbzusatz. In: Drosdowski u. a. (Hrsg.) Die Grammatik der deutschen Gegenwartssprache: unentbehrlich für richtiges Deutsch. (= Duden Bd. 4). Mannheim/Wien/Zürich: Dudenverlag.

Öhlschläger, Günther. 1989. Zur Sytax und Semantik der Modalverben des Deutschen. In: Altmann, Hans u. a. (Hrsg.) Linguistische Arbeiten Bd. 144. Tübingen: Max Niemeyer Verlag.

Redder, Angelika. 1983. Modalverben im Diskurs. In: Studien zur Verwendung der Modalverben (Studien zur deutschen Grammatik; Bd. 19). Wer-ner, Abraham u. a. Hrsg. Tübingen: Günther Narr Verlag.

Redder, Angelika (1984): Modalverben im Unterrichtsdiskurs: Pragmatik der Modalverben am Beispiel eines institutionellen Diskurses (=Reihe Germanistische Linguistik Bd. 54). Tübingen: Max Niemeyer Verlag.

Ridwan, Agus. 2014a. Deutsche und Indonesische Modalverben - Eine vergleichende Analyse. Dissertationsarbeit. Universität Mannheim: Philosophische Fakultät.

Ridwan, Agus. 2014b. Grammatikalisierung der präpositionalen Präfixe dalam Seminar Nasional Paramasastra. Universitas Negeri Surabaya: Fakultas Bahasa dan Sastra.

Ridwan, Agus. 2015. Perkembangan Verb Modal Bahasa Jerman dalam Bunga Rampai Linguistik. Surabaya: CV Bintang. 
Agus Ridwan, Gramatikalisasi Verba (hal 131-153)

Zifonun, Gisele dkk. 1997a. Grammatik der deutschen Sprache, 1 Bde. In: Eroms, Hans-Werner/Stickel, Gerhard/Zifonun, Gisela (Hrsg.) Schriften des Insituts für deutsche Sprache 7, 1-3. Berlin/New York: Walter de Gruyter. Zifonun, Gisele dkk. 1997a. Grammatik der deutschen Sprache, 2 Bde. In: Eroms, Hans-Werner/Stickel, Gerhard/Zifonun, Gisela (Hrsg.) Schriften des Insituts für deutsche Sprache 7, 1-3. Berlin/New York: Walter de Gruyter. Zifonun, Gisele dkk. 1997a. Grammatik der deutschen Sprache, 3 Bde. In: Eroms, Hans-Werner/Stickel, Gerhard/Zifonun, Gisela (Hrsg.) Schriften des Insituts für deutsche Sprache 7, 1-3. Berlin/New York: Walter de Gruyter. Barz, Irmhild. 2009. Die Wortbildung. Unentbehrlich für richtiges Deutsch. In: Die Grammatik. Unentbehrlich für richtiges Deutsch. 9. Auflage. Mannheim - Wien - Zürich: Dudenverlag.

Brinkmann, Hennig. 1971. Die deutsche Sprache: Gestalt und Leistung. 2., neubearbei-tete und erweiterte Auflage. Düsseldorf: Pädagögischer Verlag Schwann.

Drosdowski, Günther, dkk. 1997. Deutsches Universal Wörterbuch A-Z. Mannheim: Dudenverlag.

Engel, Ulrich. 2009. Deutsche Grammatik. 2., durchgesehene Auflage. München: IUDICIUM Verlag.

Henn-Memmesheimer, Beate. 2006. Grammatikalisierungen in verschiedenen Diskurstraditionen. In: Grammatische Untersuchungen. Analysen und Reflexionen. Gisela Zifonun zum 60 Geburtstag (= Studien zur deutschen Sprache Bd. 36). Breindl, Eva/Gunkel, Lutz/Strecker, Bruno, Hrsg. Tübingen: Narr.

Hentschel, Elke/Weydt, Harald. 2003. Handbuch der deutschen Sprache. 3., völlig neu bearbeitete Auflage. Berlin/New York: Walter de Gruyter.

Hentschel, Elke/Vogel, Peter M. 2009. Deutsche Morphologie. Berlin/New York: Walter de Gruyter.

Lehman, Christian. (tanpa tahun). Sprachtheorie. Universität Erfurt: Philosophische 
Fakultät.(http://www.christianlehmann.eu/ling/ling_theo/index.html?http:// www. christianlehmann.eu/ling/ling_theo/grammatikalisierung.php diakses tanggal 10 Januari 2015).

Lehmann, Cristhian. 1995. Synsemantika. In: Syntax Teilband 2 (=Handbücher zur Sprach- und Kommunikationswissenschaft Bd. 9.2) Ungeheuer, Gerold/ Steger, Hugo/Wiegand, Herbert Ernst, Hrsg. Berlin/New York: Walter de Gruyter.

Krifka, Manfred. 2007. Grundkurs: Semantik. Institut für deutsche Sprache und Lin-guistik HU Berlin. (http://amor.cms.huberlin.de/ h2816i3x/Lehre/2007_

GK_Semantik/GK_Semantik_2007_HO.pdf> diakses tanggal 9 September 2011).

Mentrup, Wolfgang. 1973. Verben mit einem Verbzusatz. In: Drosdowski u. a. (Hrsg.) Die Grammatik der deutschen Gegenwartssprache: unentbehrlich für richtiges Deutsch. (= Duden Bd. 4). Mannheim/Wien/Zürich: Dudenverlag.

Öhlschläger, Günther. 1989. Zur Sytax und Semantik der Modalverben des Deutschen. In: Altmann, Hans u. a. (Hrsg.) Linguistische Arbeiten Bd. 144. Tübingen: Max Niemeyer Verlag.

Redder, Angelika. 1983. Modalverben im Diskurs. In: Studien zur Verwendung der Modalverben (Studien zur deutschen Grammatik; Bd. 19). Wer-ner, Abraham u. a. Hrsg. Tübingen: Günther Narr Verlag.

Redder, Angelika. 1984: Modalverben im Unterrichtsdiskurs: Pragmatik der Modalverben am Beispiel eines institutionellen Diskurses (=Reihe Germanistische Linguistik Bd. 54). Tübingen: Max Niemeyer Verlag.

Ridwan, Agus. 2014a. Deutsche und Indonesische Modalverben - Eine vergleichende Analyse. Dissertationsarbeit. Universität Mannheim: Philosophische Fakultät.

Ridwan, Agus. 2014b. Grammatikalisierung der präpositionalen Präfixe dalam Seminar Nasional Paramasastra. Universitas Negeri Surabaya: Fakultas Bahasa dan Sastra.

152 | E-ISSN: 2527-8754 http:// journal.unesa.ac.id/index.php/Paramasastra 
Agus Ridwan, Gramatikalisasi Verba (hal 131-153)

Ridwan, Agus. 2015. Perkembangan Verb Modal Bahasa Jerman dalam Bunga Rampai Linguistik. Surabaya: CV Bintang.

Zifonun, Gisele dkk. 1997a. Grammatik der deutschen Sprache, 1 Bde. In: Eroms, Hans-Werner/Stickel, Gerhard/Zifonun, Gisela (Hrsg.) Schriften des Insituts für deutsche Sprache 7, 1-3. Berlin/New York: Walter de Gruyter.

Zifonun, Gisele dkk. 1997a. Grammatik der deutschen Sprache, 2 Bde. In: Eroms, Hans-Werner/Stickel, Gerhard/Zifonun, Gisela (Hrsg.) Schriften des Insituts für deutsche Sprache 7, 1-3. Berlin/New York: Walter de Gruyter. Zifonun, Gisele dkk. 1997a. Grammatik der deutschen Sprache, 3 Bde. In: Eroms, Hans-Werner/Stickel, Gerhard/Zifonun, Gisela (Hrsg.) Schriften des Insituts für deutsche Sprache 7, 1-3. Berlin/New York: Walter de Gruyter. 